\title{
THE AGE AND ORIGIN OF THE LIMPOPO (SOUTH AFRICA) SUBCONTINENTAL LITHOSPHERIC MANTLE
}

\author{
Q.H.A. van der Meer ${ }^{1,3}$, M. Klaver ${ }^{1}$, L. Reisberg ${ }^{2}$, G.R. Davies*1 \\ ${ }^{1}$ Faculty of Earth and Life Sciences, VU University Amsterdam, De Boelelaan 1085, 1081HV Amsterdam, The Netherlands; \\ ${ }^{2} C R P G, 15$ rue Notre-Dame des Pauvres, B.P. 20, 54501 Vandoeuvre-les-Nancy, France; \\ ${ }^{3}$ Institute for Geography and Geology, University of Copenhagen, Øster Voldgade 10, 1350 Copenhagen K, Denmark \\ * Corresponding author: gareth.davies@falw.vu.nl
}

\section{INTRODUCTION}

The Limpopo Mobile Belt (LMB) represents the suture zone between the Kaapvaal and Zimbabwe cratons (Southern Africa), but the timing of the collision is still highly debated (Rigby et al., 2007). Mantle tomography indicates a clear continuation of cold and thick subcratonic mantle beneath the LMB and the adjacent cratons (James et al., 2001). The crust of the central zone of the LMB is interpreted as an exotic terrane accreted to the Kaapvaal Craton (Roering et al., 1992) but the affinity of the underlying lithospheric mantle has not yet been addressed.

Located in the central zone of the LMB, mantle xenoliths from the Venetia kimberlite diatreme cluster provide an unequalled opportunity to study the origin of the Limpopo sub-continental lithospheric mantle (SCLM). As a result of the Cambrian (533 Ma, Allsopp et. al., 1995) emplacement age, mantle xenoliths from the Venetia Kimberlite are undisturbed by Palaeozoic magmatic events such as the eruption of the Karoo flood basalts and the majority of group 1 and 2 kimberlites in Southern Africa. These younger magmatic events are argued to be (in part) the cause of cryptic and modal metasomatism evident for instance in mantle xenoliths from Kimberley (e.g. Simon et al., 2003). Hence, Venetian xenoliths have the potential to retain the signatures of ancient metasomatic processes.

Great care was taken during sample selection to avoid samples affected by metasomatism related to kimberlite magmatism or too weathered for analysis. 35 fresh peridotitic xenoliths were selected from $\sim 1000$ examined mantle samples in drilled cores and stockpiles. The selected lherzolites and harzburgites have been analysed for petrography and whole rock major element composition, as well as mineral (olivine, opx, cpx, garnet and spinel) major and trace elements. In addition, we present an extensive (22 peridotite samples) whole rock Re-Os dataset and cpx+garnet Lu-Hf and Sm-Nd isotope data on 12 samples.

\section{MELT DEPLETION}

Whole rock major element data indicate that sampled xenoliths are melt depleted in nature (figure 1). Both harzburgites and lherzolites are rich in compatible and depleted in magmaphile elements relative to fertile mantle. Subsequent contamination by small amounts of a kimberlitetype magma is indicated by relative enrichment in the most incompatible elements $\left(\mathrm{K}_{2} \mathrm{O}, \mathrm{P}_{2} \mathrm{O}_{5}\right.$ $\mathrm{Na}_{2} \mathrm{O}$ and in most samples $\mathrm{TiO}_{2}$ ). Olivine $\mathrm{Mg} \#$ can be used to infer the degree of melting. The majority of our samples have olivine $\mathrm{Mg} \#$ of 91.2 to 93.6 , indicating $\sim 25->50 \%$ melt depletion (Pearson \& Wittig 2008). These Mg\# values correspond to those found in olivine inclusions in diamond from Venetia (Viljoen et al., 1999). The inferred residual lithology from such extensive melt depletion would be garnet free dunite and 


\section{0 $^{\text {th }}$ International Kimberlite Conference, Bangalore - 2012}

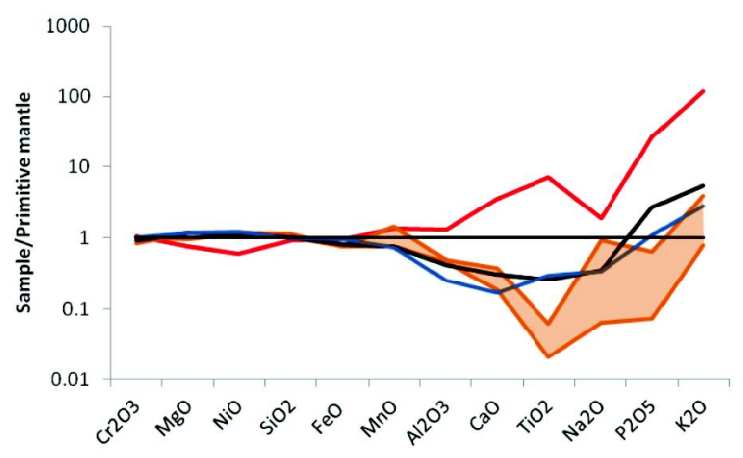

Figure 1. Primitive mantle (average fertile lherzolite from Vitim, Ionov et al., 2005) normalised whole rock major element concentrations. The orange field displays the variation of coarse lherzolites. The black line is representative for sheared lherzolites and the blue line is representative for harzburgites. Elements are sorted in order of decreasing compatibility. Venetian kimberlite (unpublished) is shown for reference as a red line.

harzburgite (Bernstein et al., 2007). The more fertile lithologies found imply that the Venetian lithosphere is the product of re-enrichment after initial depletion.

From trace element abundances it can be inferred that the initial melt depletion occurred in the absence of garnet and by implication at low pressures. This is in agreement with earlier modelling by Hin et al. (2009). Figure 2 shows the whole rock $\mathrm{Lu} \mathrm{v}$. $\mathrm{Yb}$ variation, reconstructed from mineral concentrations and modal abundances, of all analysed lherzolites and harzburgites. All but one of the analysed samples follows a melting trend at 2-3 GPa (Wittig et al., 2008).

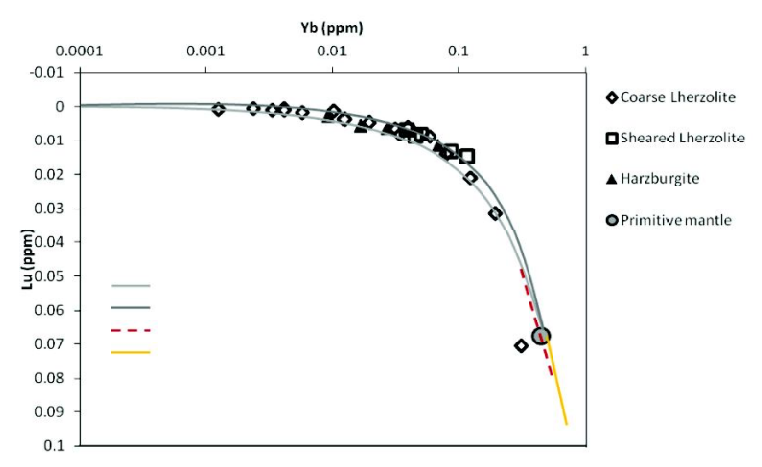

Figure 2. Reconstructed whole rock $\mathrm{Lu}-\mathrm{Yb}$ concentration variations. Melting models from Wittig et al. (2008).
The timing of melt depletion has been constrained by analysis of whole rock Re-Os isotopes. The parent element rhenium is mildly incompatible during mantle melting in contrast to the compatible daughter osmium. Therefore the age of melt extraction is recorded in the residual mantle. Rhenium depletion ages $\left(\mathrm{T}_{\mathrm{RD}}\right)$ (Walker et al., 1989) of 22 analysed lherzolites and harzburgites range between 1.3 and $3.3 \mathrm{Ga}$ with a median of $2.5 \mathrm{Ga} .12$ samples yielded realistic (i.e. between 0 and $4.5 \mathrm{Ga}$ ) CHUR model ages $\left(\mathrm{T}_{\mathrm{MA}}\right)$ (Pearson 1999). The remaining samples yielded future $\mathrm{T}_{\mathrm{MA}}$ ages or ages older than the Earth, indicative of late Re addition. The geologically significant $\mathrm{T}_{\mathrm{MA}}$ ages range between 2.1 and 3.8 Ga with a median of $3.1 \mathrm{Ga}$. From the probability density plots (see figure 3 ) it is evident that both model ages have a well defined peak. The $\mathrm{T}_{\mathrm{RD}}$ is defined at $\sim 2.6 \mathrm{Ga}$ while the $\mathrm{T}_{\mathrm{MA}}$ have an age of $\sim 3.1 \mathrm{Ga}$.

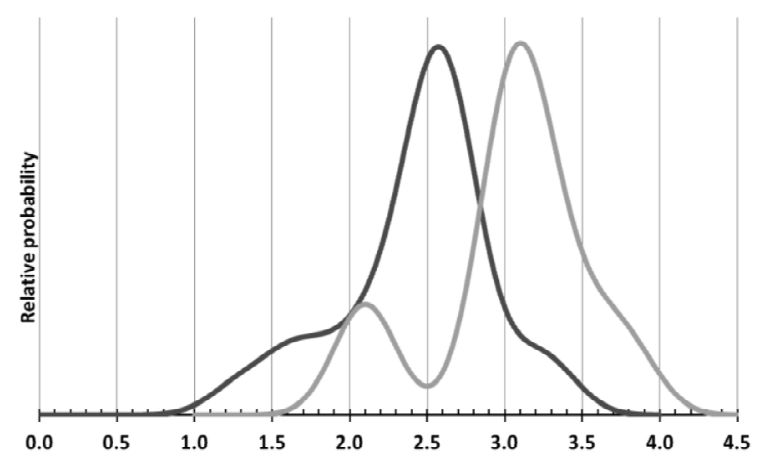

Figure 3. Probability density plot of Os model ages. A default 1ó error of $0.2 \mathrm{Ga}$ was assigned to all calculated ages. Reference chondrite as in Pearson \& Wittig (2008), $\mathrm{n}$ indicates the number of samples plotted for each population.

$\mathrm{T}_{\mathrm{RD}}$ represents a minimum estimate of the time of melt depletion. $\mathrm{T}_{\mathrm{RD}}$ ages are not easily disturbed by metasomatism and kimberlite interaction and are therefore generally considered to provide the best estimate for the depletion age in rocks that have undergone very high degrees of melting (Pearson et al., 2004). In contrast, preeruption interaction of xenoliths with kimberlite- 


\section{$1^{\text {th }}$ International Kimberlite Conference, Bangalore - 2012}

like magmas would introduce more scatter to $\mathrm{T}_{\mathrm{MA}}$ ages through Re addition. Due to the selection of non-modally metasomatised samples, the well constrained peak at $\sim 3.1$ Ga may be significant. Multiple samples with a $\mathrm{T}_{\mathrm{RD}}$ of $2.6 \pm 0.2 \mathrm{Ga}$ have corresponding $\mathrm{T}_{\mathrm{MA}}$ of $3.1 \pm 0.2$ Ga suggesting a consistent geological history. The large inferred degree of melt extraction recorded by these samples (25\%-50\%), however, suggests that these rocks would have lost all their Re and should be completely Refre(Walker et al., 1989). Therefore the Re evolution must have been complex, involving depletion and ancient Re-enrichment. The true ages of melt depletion would then lie between the $\mathrm{T}_{\mathrm{RD}}$ of $\sim 2.6 \mathrm{Ga}$ and the $\mathrm{T}_{\mathrm{MA}}$ of $\sim 3.1$ $\mathrm{Ga}$. An earlier assumed melt depletion age of 3.68 $\mathrm{Ga}$ (Carlson et al., 1999), based on the $\mathrm{T}_{\mathrm{RD}}$ model age from the analysis of one sample is unsupported by our new dataset. Based on our data set, such early melt depletion is considered unlikely to be representative of the lithosphere beneath the LMB central zone.

Additionally one of the analysed coarse lherzolite samples has an extremely low Re/Os ratio of 0.004 yielding nearly identical $\mathrm{T}_{\mathrm{MA}}$ and $\mathrm{T}_{\mathrm{RD}}$ ages of $2.0 \mathrm{Ga}$. One garnet clinopyroxenite was also analysed (not shown in figure 3). This sample has a very high $\mathrm{Re} / \mathrm{Os}$ ratio of 7.3 resulting in a $\mathrm{T}_{\mathrm{MA}}$ age of $2.6 \mathrm{Ga}$. Because of their extreme $\mathrm{Re} / \mathrm{Os}$ ratios these samples have very robust model ages that that are significantly different from the bulk of the analysed samples. These ages are interpreted to represent later more localised events that correlate with tectonism and magmatism recorded in the LMB central zone crust (Zeh et al., 2007).

\section{RE-ENRICHMENT}

The majority of the Venetian mantle samples are strikingly rich in orthopyroxene, a feature they have in common with the Kaapvaal Craton (Boyd 1989). Figure 4 shows that the majority of Venetian peridotites have relatively low olivine

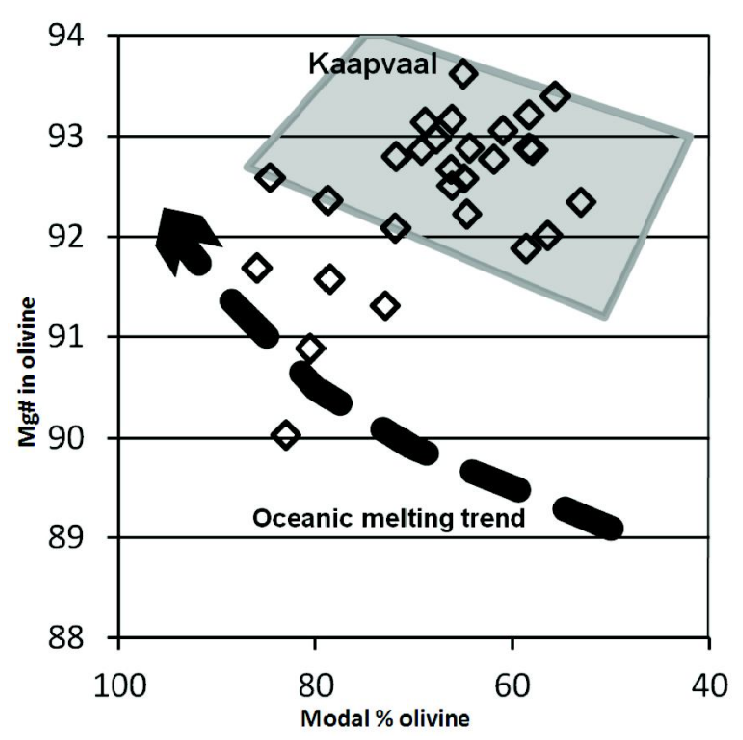

Figure 4. Mg\# in olivine plotted against modal \% olivine for each sample. Thick black line indicates the oceanic melting trend, gray field represents typical Kaapvaal mantle xenoliths. After Boyd (1989).

abundances considering the olivine $\mathrm{Mg \#}$ and plot within the Kaapvaal reference field. From the petrographically equilibrated textural relations between orthopyroxene and olivine it is inferred that $\mathrm{Si}$ enrichment occurred a significant time before kimberlite eruption allowing the minerals to reach textural equilibrium. Silica enrichment is unrelated to kimberlite metasomatism. The Zimbabwe Craton to the north of the LMB does not display such pronounced enrichment in silica (Smith et al., 2009)

Garnet and clinopyroxene present in the samples are predominantly the product of metasomatic re-enrichment of the lithosphere. Rare Earth Element (REE) concentrations in garnet, clinopyroxene and orthopyroxene vary greatly between samples but pristine minerals within a sample are generally homogeneous. Some samples have minor core to rim variations but only core analyses are considered in detail here. All samples retain an $\mathrm{Yb}$-Lu signature created during garnet absent melting. The presence of garnet and clinopyroxene and the abundance of REE in these 


\section{0 $^{\text {th }}$ International Kimberlite Conference, Bangalore - 2012}

phases can be explained by Si-Al-Ca-REE metasomatism after depletion. Figure 5 shows a selection of garnet analyses, representing the variation of REE patterns between coarse lherzolites and harzburgites and the typical pattern of garnet in sheared lherzolites.

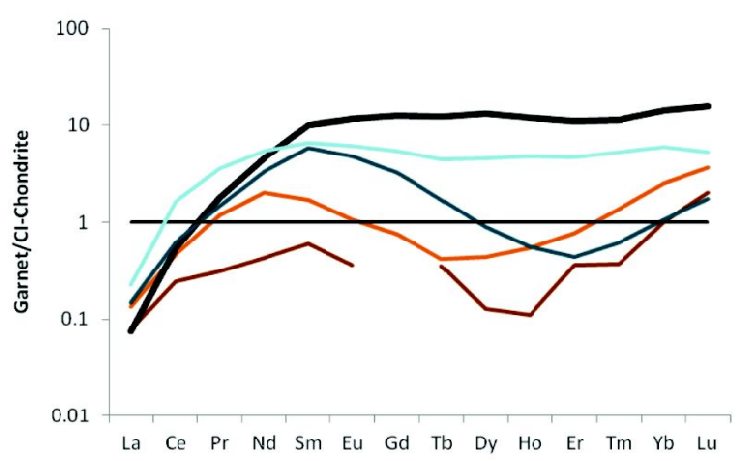

Figure 5. Chondrite normalised (Sun \& McDonough, 1989) REE patterns for garnets from representative samples. Brown line represents garnet from the most REE depleted coarse lherzolite sample (kinking and gaps in pattern due to Laser Ablation ICP-MS detection limit). Orange line: sinusioidal REE pattern with intermediate REE concentrations in garnet. Thick black line: REE pattern representative of REE rich garnet in coarse lherzolites and all sheared lherzolites. Dark blue line: harzburgite with lowest garnet REE content. Light blue line: sample representative of garnet of most harzburgite samples with high REE content.

Garnet in all samples is REE enriched to some extent. Clinopyroxene also shows large variations in REE content, with LREE between 10 and hundreds times chondrite and HREE generally below LA-ICP-MS detection limits. Sm$\mathrm{Nd}$ isotope analyses of garnet and clinopyroxene can be used to constrain the timing of the reenrichment in the LREE. Garnet-cpx isochron ages range from -300 to $\sim 1600 \mathrm{Ma}$. These ages are considered to be a consequence of mixing between metasomatic components and the protolith and subsequent inter-element diffusion rather than the age of garnet and/or cpx introduction. This is supported by the low initial ${ }^{143} \mathrm{Nd} /{ }^{144} \mathrm{Nd}$ ratios of the gt-cpx isochrons: 0.5103 0.5107 , indicating ancient enrichment. In contrast, one sample has an initial neodymium isotope composition within error of Venetian kimberlite (Seggie et al., 1999). The low initial ${ }^{143} \mathrm{Nd} /{ }^{144} \mathrm{Nd}$ ratios of most minerals suggest that re-enrichment is ancient, most probably Archaean. Additional evidence for early metasomatism is provided by late Archaean to early Proterozoic CHUR model ages of clinopyroxene from (gt-free) spinellherzolites.

An exception to the general sample trace element homogeneity is the local positive $\mathrm{La}$ excursions in garnet analyses of some samples and positive La-Nd excursions in orthopyroxene. These elevated LREE concentrations are shown to be in disequilibrium with the other mineral phases in the sample based on partitioning modelling (e.g., Lee et al., 2007). Spatial analysis of garnet grains in a coarse lherzolite sample containing a small kimberlite melt vein has shown that the disequilibrium in LREE in garnet increases in proximity to a kimberlitic vein. At the garnet-kimberlite contact enrichment of the garnet intensifies. La-Gd are elevated and in disequilibrium with the other peridotitic phases. Thus we interpret the local LREE disequilibrium as a consequence of cryptic metasomatism by the LREE-rich kimberlitic melt. The zone of cryptic LREE metasomatism is restricted to $2 \mathrm{~mm}$ from the kimberlite vein, leaving the great majority of the xenolith unaffected.

\section{DISCUSSION}

The majority of the peridotites have low HREE contents that imply extensive melt depletion followed by REE-Si and Re enrichment. Assuming that Re and REE addition were linked, the late Archaean enrichment age inferred from the $\mathrm{Nd}$ isotopes also would apply to Re. As can be seen in figure 6 , this age constraint for enrichment would require the time of initial melt depletion to be substantially older than the $T_{R D}$ age, approaching the $\mathrm{T}_{\mathrm{MA}}$ age. Therefore the $\mathrm{T}_{\mathrm{MA}}$ ages may provide reasonable estimates of the age of melt depletion of the LMB central zone. 


\section{$1^{\text {th }}$ International Kimberlite Conference, Bangalore - 2012}

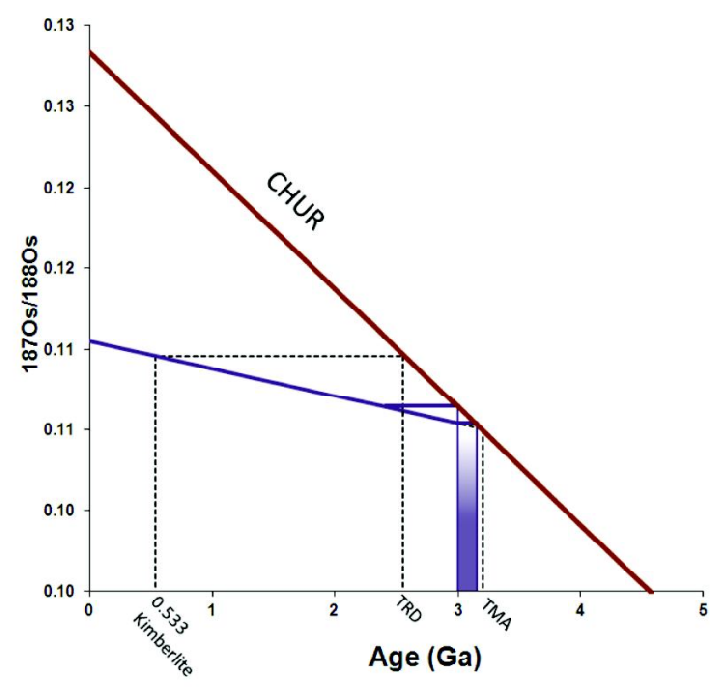

Figure 6. Os isotope evolution diagram of a sample with a $T_{R D}$ of $2.6 \mathrm{Ga}$, shown as dashed green lines and a $\mathrm{T}_{\mathrm{MA}}$ of $3.2 \mathrm{Ga}$. Purple lines indicate the evolution of this sample after late Archaean Reenrichment (age constrained by $\mathrm{Nd}$ isotopes). Purple field indicate age range of initial melt depletion in the Archaean. Brown line is Chondrite Os isotopic evolution. Kimberlite eruption at $0.533 \mathrm{Ga}$.

When a $0.2 \mathrm{Ga}$ error is taken into account, the $\sim 3.1 \mathrm{Ga} \mathrm{T}_{\mathrm{MA}}$ age is coeval with the $3.28 \mathrm{Ga}$ formation age of the oldest crustal unit of the LMB central zone, the Sand River Granitioid Suite (TTG) of the Beit bridge complex (Zeh et al., 2007). The Sand River Granitoid Suite is interpreted to have once been a widespread unit within the central zone that has been largely overprinted by later metamorphic and magmatic events (Kroner et al., 1999). This would imply a coupling between crust and mantle for the LMB central zone from at least $\sim 3.28 \mathrm{Ga}$.

\section{CONCLUSIONS}

The continental lithospheric mantle beneath the LMB underwent high degrees of partial melting in the Archaean, possibly at the time of the $\sim 3.28 \mathrm{Ga}$ crust formation episode in the region, which may be recorded as $\sim 3.1$ Ga Re-Os model ages in many of the peridotites. The resulting depleted residua were subsequently re-enriched in $\mathrm{Si}, \mathrm{REE}$ and $\mathrm{Re}$, with a component of $\mathrm{Al}$ and $\mathrm{Ca}$. Initial ratios of two point clinopyroxenegarnet $\mathrm{Sm}-\mathrm{Nd}$ isochrons indicate that enrichment was ancient and may have occurred in a single event as early as the Archaean. The majority of the lithospheric mantle beneath the LMB central zone was depleted and enriched in the Archaean. One pyroxenite and one coarse lherzolite record evidence of local magmatic events at $\sim 2.6 \mathrm{Ga}$ and at $\sim 2.0 \mathrm{Ga}$. However, the majority of the lithospheric mantle suffered no major magmatic events between initial (Archaean) enrichment and eruption of the kimberlite in the Cambrian.

\section{References}

Allsopp, H. L., Smith, C.B., Seggie, A.G., Skinner, E.M.W., Colgan, E.A. (1995). "The emplacement age and geochemical character of the Venetia kimberlite bodies, Limpopo belt, Northern Transvaal." S Afr. J. Geol. 98: 239-244.

Bernstein, S., Kelemen, P.B. and Hangøj, K., 2007. Consistent olivine $\mathrm{Mg} \#$ in cratonic mantle reflects Archean mantle melting to the exhaustion of orthopyroxene. Geology, 35(5): 459-462.

Boyd, F.R., 1989. Compositional distinction between oceanic and cratonic lithosphere. Earth and Planetary Science Letters, 96(1-2): 15-26.

Carslon, R. W., Pearson, D.G., Boyd, F.R., Shirey, S.B., Irvine, G., Menzies, A.H., Gurney, J.J. (1999). ReOs systematics of lithospheric peridotites: implications for lithosphere formation and preservation. Proceedings of the 8th International Kimberlite Conference, the J. Barry Hawthorne Volume. J. L.

Hin, R.C. et al., 2009. Formation and temporal evolution of the Kalahari sub-cratonic lithospheric mantle: Constraints from Venetia xenoliths, South Africa. Lithos, 112(Supplement 2): 1069-1082.

Ionov, D. A., Ashchepkov, I., Jagoutz, E. (2005). “The provenance of fertile off-craton lithospheric mantle: $\mathrm{Sr}-\mathrm{Nd}$ isotope and chemical composition of garnet and spinel peridotite xenoliths from Vitim, Siberia." Chem. Geol. 217: 41-75.

James, D.E., Fouch, M.J., VanDecar, J.C., van der Lee, S. and Kaapvaal Seismic, G., 2001. Tectospheric 


\section{$10^{\text {th }}$ International Kimberlite Conference, Bangalore - 2012}

structure beneath southern Africa. Geophys. Res. Lett., 28(13): 2485-2488.

Kroner, A., Jaeckel, P., Brandl, G., Nemchin, A. A. \& Pidgeon, R. T. (1999). Single zircon ages for granitoid gneisses in the Central Zone of the Limpopo Belt, Southern Africa and geodynamic significance. Precambrian Research 93, 299-337.

Lee, C. A., Harbert, A., Leeman, W.P. (2007). "Extension of lattice strain theory to mineral/ mineral rare- earth element partitioning: An approach for assessing disequilibrium and developing internally consistent partition coefficients between olivine, orthopyroxene, clinopyroxene and basaltic melt." Geochim. et Cosmochim. Acta 71: 481-496.

Pearson, D.G. 1999. The age of continental roots. Lithos, 48, 171-194.

Pearson, D.G., Irvine, G.J., Ionov, D.A., Boyd, F.R. \& Dreibus, G.E. 2004.Re-Os isotope systematics and Platinum Group Element fractionation duringmantle melt extraction: A study of massif and xenolith peridotite suites. Chemical Geology, 208, 29-59.

Rigby, M., Mouri, H. and Brandl, G., 2008. A review of the pressure-temperature-time evolution of the Limpopo Belt: Constraints for a tectonic model. Journal of African Earth Sciences, 50(2-4): 120132.

Roering, C. et al., 1992. Tectonic model for the evolution of the Limpopo Belt. Precambrian Research, 55(1-4): 539-552.

Seggie, A.G., Hannweg, G.W., Colgan, E.A. and Smith, C.B. (1999). The geology and geochemistry of the Venetia kimberlite cluster, Northern Province, South Africa. Proceedings of the 7th International Kimberlite Conference, Cape Town, South Africa, 750-756.

Simon, N.S.C., Irvine, G.J., Davies, G.R., Pearson, D.G. and Carlson, R.W., 2003. The origin of garnet and clinopyroxene in "depleted" Kaapvaal peridotites. Lithos, 71(2-4): 289-322.
Smith, C.B. et al., 2009. Extremely depleted lithospheric mantle and diamonds beneath the southern Zimbabwe Craton. Lithos, 112(Supplement 2): 1120-1132.

Sun, S. S., McDonough, W.F. (1989). Chemical and isotopic systematics of oceanic basalts: implications for mantle composition and processes. Magmatism in the ocean basins. A. D. Saunders, Norry, M.J. London, Geol. Soc. Lond. 42: 313345

Viljoen, K. S., Phillips, D., Harris, J.W., Robinson, D.N. (1999). Mineral inclusions in diamonds from the Venetia kimberlites, Northern Province, South Africa. Proceedings of the 8th International Kimberlite Conference, the J. Barry Hawthorne volume. J. L. Gurney, Gurney, J.J., Pascoe, M.D., Richardson, S.H. Cape Town, Red Roof Design cc. 2: 888-895.

Wittig N., Pearson D.G., Webb M., Ottley C.J., Irvine G.J., Kopylova M., Jensen S.M. and Nowell G.M. (2008). Origin of cratonic lithospheric mantle roots: A geochemical study of peridotites from the North Atlantic Craton, West Greenland, Earth and Planetary Science Letters, Volume 274, Issues 12, Pages 24-33

Walker R.J., Carlson R.W., Shirey S.B. and Boyd F.R. (1989) Os, Sr, Nd and Pb isotope systematics of southern African peridotite xenoliths: Implications for the chemical evolution of subcontinental mantle. Geochimica et Cosmochimica Acta, 53, 1583-1595.

Zeh, A., Gerdes, A., Klemd, R. and Barton, J.M., 2007. Archaean to Proterozoic Crustal Evolution in the Central Zone of the Limpopo Belt (South AfricaBotswana): Constraints from Combined $\mathrm{U}-\mathrm{Pb}$ and Lu-Hf Isotope Analyses of Zircon. Journal of Petrology, 48(8): 1605-1639. 